\title{
PEMASARAN JASA PENDIDIKAN \\ SEBAGAI STRATEGI \\ PENINGKATAN MUTU \\ DI SD ALAM BATURRADEN
}

\section{Afidatun Khasanah}

Program Magister Pendidikan Islam, Fakultas Ilmu Tarbiyah dan Keguruan, UIN Sunan Kalijaga Yogyakarta

Email: khasanahafidatun556@gmail.com

DOI: http://dx.doi.org/10.20885/tarbawi.vol8.iss2.art4

\section{Abstract}

This paper focuses on the marketing of education services by educational institutions which are now facing a lot of challenges in this global era. The marketing of education services is a strategy to improve the quality of education which is an important element for the quality and level of advancement of education of particular institution. This paper will discuss more specifically how marketing is applied in SD Alam Baturraden as a strategy to increase the quality of its education. Furthermore, it looks at how widespread marketing of educational services has departed from the original concept of the school as a non-profit institution which is not a business area in the world of education.

Keywords: marketing, education services, quality

\section{Abstrak}

Fokus pembahasan tulisan ini adalah pada pemasaran jasa pendidikan di lembaga pendidikan yang kini memiliki banyak tantangan di era global. Pemasaran jasa pendidikan merupakan strategi peningkatan mutu pendidikan yang merupakan elemen terpenting bagi kualitas serta kemajuan taraf pendidikan pada suatu lembaga pendidikan. Tulisan ini secara khusus akan membahas bagaimanakah pemasaran yang diterapkan di SD Alam Baturraden sebagai strategi peningkatan mutu pendidikan yang ditawarkannya. Lebih lanjut, tulisan ini melihat secara kritis bagaimana maraknya pemasaran jasa pendidikan beranjak dari konsep awal sekolah sebagai lembaga pendidikan nirlaba dan bukan sebagai 
lahan bisnis dalam dunia pendidikan.

Kata Kunci: pemasaran, jasa pendidikan, mutu

\section{Pendahuluan}

Sekolah merupakan lembaga pendidikan nirlaba yang bergerak dalam bidang jasa pendidikan. Selain itu kompetisi antar sekolah pun semakin ketat. Maka dalam hal ini penyelenggara pendidikan dituntut untuk kreatif dalam menggali keunikan dan keunggulan sekolahnya agar dibutuhkan dan diminati oleh pelanggan jasa pendidikan. Munculnya sekolah bertaraf internasional serta lahirnya sekolah negeri dan swasta yang menawarkan keunggulan fasilitas, bahkan dengan biaya yang terjangkau, dapat menambah maraknya kompetisi pendidikan. Aktivitas pemasaran jasa pendidikan yang dahulu dianggap tabu karena berbau bisnis dan cenderung berorientasi pada laba, sekarang ini sudah dilakukan secara terbuka. Karena jasa pendidikan memegang peran penting untuk mengembangkan dan meningkatkan kualitas sumber daya manusia.

Sekolah yang berkualitas merupakan impian seluruh elemen bangsa karena akan melahirkan kader-kader berkualitas yang mampu membawa perubahan besar bagi bangsa. Menurut Sudarwan Danim, sekolah berkualitas tinggi merupakan sekolah yang memuaskan pelanggan.

Di tengah krisis multidimensi yang mendera bangsa ini, terwujudnya lembaga pendidikan berkualitas tinggi menjadi kebutuhan yang tidak bisa ditawar. Oleh sebab itu, setiap elemen khususnya para praktisi pendidikan harus berjuang lebih kolektif kolegial untuk memajukan lembaga pendidikan yang menjadi tumpuan utama kemajuan bangsa. Peningkatan mutu menjadi tantangan utama pada setiap jalur, jenis dan jenjang pendidikan. Mutu harus ditingkatkan agar lembaga pendidikan mampu memberikan makna bagi bekal kehidupan anak didik di masa depan. Pemasaran menjadi salah satu mutu penggerak kemajuan lembaga pendidikan. Tantangan era global semakin kompleks dan harus direspon dengan kehadiran lembaga pendidikan berkualitas tinggi (Jamal Ma'mur Asmani, 2015: 116).

\section{Pembahasan}

Pemasaran adalah suatu proses sosial dan managerial yang melibatkan kegiatan-kegiatan penting yang memungkinkan individu dan 
kelompok mendapatkan kebutuhan dan keinginan melalui pertukaran dengan pihak lain dan untuk mengembangkan hubungan pertukaran. Proses pemasaran sangat dipengaruhi oleh berbagai faktor seperti sosial, budaya, politik, ekonomi, dan managerial. Akibat dari pengaruh tersebut, individu mendapatkan kebutuhan dan keinginan mereka dengan menciptakan, menawarkan, dan bertukar sesuatu yang bernilai satu sama lain (Imam Machali, 2015: 390)

Dapat ditarik sebuah kesimpulan bahwa pemasaran merupakan suatu proses sosial dan managerial di mana individu dan kelompok mendapatkan kebutuhan dan keinginan mereka dengan menciptakan, menawarkan dan bertukar sesuatu yang bernilai satu sama lain. Pemasaran tidak hanya berfungsi menyampaikan produk atau jasa hingga sampai ke tangan konsumen, tetapi bagaimana produk atau jasa tersebut dapat memberikan kepuasan kepada pelanggan dengan menghasilkan laba.

Kotler (2003: 428) mengartikan jasa sebagai setiap tindakan atau kinerja yang ditawarkan oleh satu pihak pada pihak yang lainnya yang secara prinsip tidak berwujud dan tidak menyebabkan kepindahan kepemilikan. Karakteristik jasa dapat diartikan sebagai berikut:

a. Tidak berwujud (intangible), sehingga konsumen tidak dapat melihat, mencium, meraba, mendengar dan merasakan sebelum mereka membelinya.

b. Tidak terpisahkan (inseparability), yakni jasa tidak dapat dipisahkan dari sumbernya.

c. Bervariasi (variability) di mana jasa seringkali berubah-rubah tergantung siapa, kapan dan di mana penyajiannya.

d. Mudah musnah (perishability), tidak dapat dijual pada masa yang akan datang.

e. Jasa tidak dapat disimpan dan dikonsumsi pada saat dihasilkan.

f. Konsumen merupakan bagian internal dari proses produksi jasa.

g. Setiap orang atau apapun yang ikut berhubungan dengan konsumen mempunyai andil dalam memberika peranan.

h. Karyawan penghubung merupakan bagian dari proses produksi jasa.

i. Kualitas jasa tidak dapat diperbaiki pada saat proses produksi karena produksi jasa terjadi secara real time (Imam Machali, 2015: 397). 
Berdasarkan ciri dan karakteristik tersebut, maka jasa pendidikan mempunyai karakteristik sebagai berikut:

a. Lebih bersifat tidak berwujud daripada berwujud

b. Produksi dan konsumsi bersamaan waktu

c. Kurang memiliki standar dan keseragaman (David Wijaya, 2012: 5).

Menurut Lovelock (2004) jasa dapat didefinisikan ke dalam tiga hal sebagai berikut:

1. Tindakan atau perbuatan yang ditawarkan satu kelompok pada kelompok yang lain.

2. Aktifitas ekonomi yang menciptakan nilai serta menyediakan manfaat bagi pelanggan pada waktu dan tempat tertentu.

3. Sesuatu yang dapat dibeli dan dijual.

Untuk menunjukkan masalah umum yang terjadi secara lintas sektor, Schmenner (1986) mengklasifikasikan jasa matriks proses jasa. Dalam matriks tersebut, jasa diklasifikasikan menjadi dua dimensi yang secara signifikan dapat mempengaruhi proses penyampaian jasa, yaitu:

1. Dimensi vertikal, mengukur besarnya intensitas tenaga kerja terhadap modal biaya.

2. Dimensi horizontal, mengukur tingkat interaksi dan kustomisasi pelanggan (David Wijaya 2012: 8).

Pemasaran dalam konteks jasa pendidikan adalah sebuah proses sosial dan managerial untuk mendapatkan apa yang dibutuhkan dan diinginkan melalui penciptaaan penawaran, pertukaran produkyang bernilai dengan pihak lain dalam bidang pendidikan. Etika layanan pemasaran dalam dunia pendidikan adalah menawarkan mutu layanan intelektual dan pembentukkan watak secara menyeluruh. Karena pendidikan bersifat lebih kompleks, yang dilaksanakan dengan penuh tanggungjawab, hasil pendidikannya mengacu jauh kedepan, membina kehidupan warga negara, generasi penerus di masa mendatang (Imam Machali 2015: 397).

Lockhart (2005) menyebutkan lima faktor yang mendorong pemasaran jasa pendidikan di antaranya:

1. Meningkatnya kompetisi

2. Perubahan demografi

3. Ketidakpercayaan masyarakat 


\section{Penyelidikan media}

5. Keterbatasan sumber daya (David Wijaya, 2012: 2).

Pemasaran jasa pendidikan bukan merupakan kegiatan bisnis agar sekolah yang dikelola mendapat siswa, tetapi merupakan tanggungjawab penyelenggara pendidikan terhadap masyarakat luas tentang jasa pendidikan yang telah, sedang, dan akan dilakukannya.

Dalam pemasaran, kepuasan pelanggan merupakan faktor penting yang perlu diperhatikan. Hal ini disebabkan karena pendidikan merupakan proses sirkuler yang saling mempengaruhi dan berkelanjutan. Hal tersebut dapat menjadi sinyal positif dalam peningkatan mutu penyelenggaraan pendidikan. Salah satu manfaat dalam pemasaran jasa pendidikan adalah terciptanya lingkungan belajar yang baik bagi seluruh siswa (David Wijaya, 2012: 3) Dalam pemasaran, kepuasan pelanggan yakni respons konsumen yang sudah terpenuhi keinginannya tentang penggunaan barang atu jasa yang mereka pakai. Dalam pengukuran kepuasan pelanggan, Kotler (2000: 38) mengemukakan beberapa cara di antaranya:

1. Complaint and suggestion system (sistem keluhan dan saran), informasi dari keluhan dan saran ini akan dijadikan data dalam melakukan antisipasi dan pengembangan.

2. Costumer satisfication surveys (survey kepuasan pelanggan), tingkat keluhan konsumen dijadikan data dalam mengukur tentang kepuasan,

3. Ghost shopping (pembeli bayangan), dengan mengirimkan orang untuk melakukan pembelian di perusahaan orang lain maupun di perusahaan sendiri untuk melihat jelas keunggulan dan kelemahan pelayanannya,

4. Lost customer analysis (analisis pelanggan yang beralih), yaitu kontak yang dilakukan kepada pelanggan yang telah beralih pada perusahaan lain untuk dilakukan perbaikan kinerja dalam meningkatkan kepuasan.

Secara matematis, kepuasan adalah selisih antara Total Customer Value dengan Total Customer cost. (Ara Hidayat dan Imam machali, 2010:264)

Kepuasan = Total Customer Value - Total Customer Cost 
Dalam pemasaran pendidikan, sangat dibutuhkan adanya bauran pemasaran dalam pendidikan. Bauran pemasaran dalam konteks pendidikan adalah unsur-unsur yang sangat penting dan dapat dipadukan sedemikian rupa sehingga dapat menghasilkan strategi pemasaran yang dapat digunakan untuk memenangkan persaingan. Bauran pemasaran merupakan alat bagi pemasar yang terdiri atas berbagai unsur suatu program pemasaran yang perlu dipertimbangkan agar implementasi strategi pemasaran dan positioning yang ditetapkan dapat berjalan sukses. Bauran pemasaran terdiri dari $7 \mathrm{P}$ yaitu product, price, place, promotion, people, physical evidence, process. Berikut adalah penjabaran dari tujuh prinsip bauran tersebut:

\section{Product (produk)}

Kotler (2000: 448) mendefinisikan produk sebagai segala sesuatu yang dapat ditawarkan ke pasar untuk memenuhi keinginan atau kebutuhan. Produk dengan kata lain adalah keseluruhan objek atau proses yang memberikan sejumlah nilai kepada konsumen.

Dalam konteks jasa pendidikan, produk adalah jasa yang ditawarkan kepada pelanggan berupa reputasi, prospek dan variasi pilihan. Lembaga pendidikan yang mampu memenangkan persaingan jasa pendidikan adalah yang dapat menawarkan reputasi, prospek, mutu pendidikan yang baik, prospek dan peluang yang cerah bagi para siswa untuk menentukan pilihan-pilihan yang diinginkannya. Sedangkan kompetensi lulusan adalah yang kualifikasi kemampuan lulusan yang mencakup sikap, pengetahuan, dan ketrampilan.

\section{Price (harga)}

Price (harga) adalah sejumlah uang yang harus dibayarkan oleh konsumen untuk mendapatkan suatu produk. Harga dalam konteks jasa pendidikan adalah seluruh biaya yang dikeluarkan untuk mendapatkan jasa pendidikan yang ditawarkan. Elemen harga pendidikan dipertimbangkan mengenai penetapan harga SPP, investasi bangunan, laboratorium dan lain-lain.

\section{Place (lokasi)}

Lokasi berarti berhubungan dengan dimana perusahaan jasa harus bermarkas dan melakukan aktivitas kegiatannya. Dalam konteks jasa pendidikan madrasah place adalah lokasi sekolah berada. Lokasi sekolah 
sedikit banyak menjadi prefensi calon pelanggan dalam menentukan pilihannya. Lokasi yang strategis, nyaman dan mudah dijangkau akan menjadi daya tarik tersendiri.

\section{Promotion (promosi)}

Promosi adalah kegiatan mengkomunikasikan penjualan produk dipasaran yang berhubungan langsung dengan masyarakat. Promosi bertujuan untuk memberikan informasi dan meyakinkan konsumen akan manfaat produk yang dihasilkan. Kegiatan promosi yang dapat dilakukan adalah dengan cara advertising melalui media TV, radio, surat kabar, buletin, dan lain-lain. Promosi penjualan juga dapat dilakukakan melalui pameran pendidikan, bazar pendidikan dan investasi, melakukan kontak langsung dengan siswa dan juga melakukan kegiatan hubungan dengan masyarakat.

\section{People (orang)}

People dalam konteks pendidikan adalah orang-orang yang terlibat dalam proses penyamaian jasa pendidikan seperti tata usaha, kepala sekolah, guru dan karyawan. Sumber daya pendidik dan kependidikan ini sangat penting bahkan menjadi ujung tombak dalam proses pemberian layanan pendidikan kepada para siswa dalam lembaga madrasah.

\section{Physical Evendence (bukti fisik)}

Physical evidence (bukti fisik) adalah lingkungan fisik tempat jasa diciptakan dan langsung berinteraksi dengan konsumennya. Terdapat dua macam bukti fisik yakni, pertama merupakan keputusan-keputusan yang dibuat oleh pemberi jasa mengenai desain dan tata letak gedung seperti desain kelas, gedung sekolah, perpustakaan, lapangan olahraga dan lain-lain.

Kedua, bukti pendukung merupakan nilai tambah yang bila berdiri sendiri tidak akan berdiri sendiri dan memiliki peran yang sangat penting dalam proses jasa seperti raport, catatan siswa dan lain-lain.

\section{Process (proses)}

Proses adalah prosedur atau mekanisme dalam rangkaian aktivitas untuk menyampaikan jasa dari produsen ke konsumen. Dalam konteks jasa pendidikan proses adalah proses pendidikan yang mendukung terselanggaranya proses kegiatan belajar mengajar guna terbentuknya produk/lulusan yang diinginkan (Imam Machali, 2015: 408-412). 
Langkah-langkah strategis pemasaran jasa pendidikan di lembaga pendidikan Islam:

1. Identifikasi Pasar

Yakni mengidentifikasi dan menganalisis pasar untuk mengetahui kondisi dan ekspektasi pasar termasuk atribut-atribut pendidikan yang menjadi kepentingan konsumen pendidikan. Dalam hal ini sesungguhnnya madrasah memiliki potensi yang tinggi dalam upaya ikut mencerdaskan bangsa dan mensukseskan program wajib belajar nasional.

2. Segmentasi Pasar dan Positioning

Segmentasi pasar membagi pasar menjadi kelompok pembeli yang dibedakan menjadi kelompok pembeli, karakteristik, atau tingkah laku yang mungkin membutuhkan produk yang berbeda. Sedangkan positioning adalah karakteristik dan pembedaan produk yang nyata yang memudahkan konsumen untuk membedakan produk jasa antara satu lembaga dengan lembaga yang lain.

3. Diferensiasi Produk

Melakukan diferensiasi merupakan cara yang efektif dalam mencari perhatian pasar. Diferensiasi merupakan salah satu dari tiga strategi pemasaran sebagai strategi bersaing yaitu:

a. Diferensiasi yakni melakukan penawaran yang berbeda dibandingkan penawaran competitor.

b. Keunggulan biaya yakni strategi mengefisienkan seluruh biaya produksi atau jasa sehingga bisa dijua lebih murah disbanding pesaing.

c. Fokus yakni strategi menggarap satu target khusus.

d. Komunikasi pemasaran

Sekolah sebagai lembaga ilmiah akan lebih elegan apabila bentuk-bentuk komunikasi disajikan dalam format ilmiah. Seperti menyelenggrakan kompetisi bidang studi, seminar, dan yang paling efektif adalah publikasi prestasi oleh media independen seperti berita dalam media massa.

4. Pelayanan sekolah

Pelayanan sekolah terlihat sebagai apa yang diharapkan konsumen. Kesenjangan yang sering terjadi adalah adanya 
perbedaan persepsi kualitas maupun atribut jasa pendidikan. Ciriciri organisasi jasa yang baik:
a. Memiliki konsep yang fokus pada konsumen
b. Komitmen kualitas dari managemen puncak
c. Penetapan standar yang tinggi
d. Sistem yang memonitor kinerja jasa
e. Sistem untuk memuaskan keluhan pelanggan
f. Memuaskan karyawan sama dengan pelanggan.

Ada lima langkah untuk mencapai ciri-ciri tersebut: keandalan, responsif, keyakinan, empati, dan wujud (Imam Machali 2015: 414420).

\section{Implementasi Bauran Pemasaran Jasa Pendidikan di SD Alam Baturraden}

1. Profil Singkat

SD Alam Baturraden (SABar) mengambil arsitektur lanskap gunung dan hutan yang mejadi kekayaan alam daerah Baturraden dan sangat kondusif untuk eksplorasi, pembelajaran dan petualangan siswa. Lokasi Sekolah Alam Baturraden yang diajukan untuk tingkat Taman Kanak-Kanak dan Sekolah Dasar adalah di petak 38-g (seluas 2,3 Ha) di wilayah kerja KPH Banyumas Timur yang merupakan pangkuan dari Lembaga Masyarakat Desa Hutan (LMDH) Wana Karya Lestari Desa Kemutug Lor Kecamatan Baturraden Kabupaten Banyumas Provinsi Jawa Tengah.

Pengelolaan Sekolah Alam Baturraden:

a. Modal produktif. Pengelolaan alam untuk pertanian dan peternakan dari praktek, pengelolahan sampah dan Wisata Pendidikan akan menghasilkan dana untuk membiayai sendiri (Swadana)

b. Sarana pengembangan manusia. Kebersamaan, keterikatan antara manusia dengan alamnya menghasilkan manusia berwawasan lingkungan.

c. Wisata pendidikan. Berbagai sarana dan fasilitas yang akan dibangun dapat dioptimalkan sebagai Wisata Pendidikan terutama pada hari libur nasional dan libur sekolah di akhir pekan (Sabtu dan Minggu). 
Metode pembelajaran yang digunakan pada SD Sekolah Alam Baturraden adalah sebagai berikut:

a. Tauladan: memberikan contoh aplikatif.

b. Pembiasaan: "bisa karena biasa" tanpa membebani.

c. Outing dan Riset: melakukan pengamatan terhadap kondisi dan fenomena alam, budaya dan masyarakat.

d. Outbound: permainan/atraksi high/low impact, tracking (lintas alam), caving (menyusuri gua) guna membangun mentalitas peserta didik.

e. Magang: menginteraksikan peserta didik dengan unit, pelaku dan lingkungan bisnis.

Sekolah Alam Baturraden adalah sekolah yang dibangun atas dasar 4 pilar pokok, yaitu:
a. Akhlakul karimah
b. Logika Ilmu pengetahuan
c. Kepemimpinan
d. Kewirausahaan

Standar kelulusan yang dimiliki oleh SD Sekolah Alam Baturraden adalah sebagai berikut:

a. Memiliki akhlakul karimah

b. Menguasai ilmu pengetahuan

c. Memiliki life skill

d. Berjiwa pemimpin

e. Berjiwa enterpreneur

f. Cinta alam dan lingkungan

Sebagai lembaga pendidikan yang bernaung di bawah payung Yayasan Masyarakat Madani Indonesia Baru, Lembaga Pendidikan Sekolah Alam Baturraden di dalam aktivitas penyelenggaraan pendidikan memiliki:

Tujuan secara umum:

a. Meningkatkan peran serta Yayasan Masyarakat Madani Indonesia Baru sebagai pusat kegiatan pendidikan, dakwah dan sosial di Banyumas.

b. Mengembangkan pelayanan pendidikan dasar bagi masyarakat Banyumas. 
Tujuan secara khusus:

a. Mengembangkan konsep sekolah alam berbasis akhlakul karimah.

b. Menyediakan sarana dan prasarana pendidikan.

c. Menyelenggarakan proses belajar mengajar.

2. Strategi Bauran Pemasaran di SD Alam Baturraden

a. Strategi Product

Produk yang ditawarkan oleh sekolah alam Baturraden kepada pelanggan merupakan produk yang secara global dapat direalisasikan dalam visi sekolah tersebut yakni menjadi kualitas output yang rahmatan lil alamiin. Hal tersebut tentunya sesuai dangan landasan yang dimiliki sekolah tersebut yakni berdasarkan Al-Quran dan Hadis. Kalimat rahmatan lil'alamin dapat dijabarkan dengan sangat luas kedalam kegiatan pembelajaran di antaranya dengan pembelajaran terintegrasi, kegiatan intra sekolah seperti Business Day, perkusi, memanah, outbound, dan kegiatan yang lain-lain. Program yang ditawarkan pun memiliki dua varian yakni program reguler dan juga program inklusi. Program inklusi difokuskan pada anak-anak yang memiliki kebutuhan khusus. Program inklusi ini memiliki kurikulum khusus inklusi dan memiliki fasilitator pendamping, selain wali kelas itu sendiri.

Sekolah yang baru berdiri 3,5 tahun ini telah memiliki ijin dari dinas pendidikan yang merupakan hal pendukung utama dalam pemasaran jasa pendidikan. Sejauh ini, SD Alam Baturraden telah mengikutsertakan serta meloloskan siswa didik mereka ke dalam beberapa kejuaraan seperti olimpiade IPA, Matematika, Catur, perlombaan Origami, dsb.

SD Alam Baturraden juga sudah mulai dikenal di kancah nasional maupun internasional. Hal tersebut dapat dibuktikan dengan adanya kedatangan sekolah alam yang lain dari berbagai daerah seperti dari Bontang, Riau, Bandung, Cilacap, Kebumen, Lampung, dll. serta kedatangan beberapa kali tamu dari Belanda dan Belgia.

Sedangkan prospek SD Alam Baturraden adalah para siswa dapat bersaing dengan siswa lain yang dan dapat hidup lebih mandiri, di mana hal tersebut sangat ditunjang oleh fasilitas 
yang diberikan oleh sekolah tersebut dengan adanya penanaman kemampuan berbisnis pada anak sejak usia dini.

b. Strategi Price

Harga yang harus dibayarkan oleh orang tua SD Alam Baturraden yakni 250.000 ,- spp perbulan, dana kegiatan pertahun 3.500.000,- (termasuk seragam, biaya kegiatan-kegiatan parenting dan juga seluruh kegiatan siswa), biaya makan dan snack perbulan 175.000,- , biaya antar jemput 200.000,- (disesuaikan dengan jarak), bagi siswa inklusi ada pendamping akademik per bulan $750.000,-$ , program terapi $150.000,-$, dan juga pendamping akademik $350.000,-$.

Orang tua difasilitasi oleh kemudahan layanan pembayaran melalui bank yang telah ditentukan oleh pihak pengelola sekolah. Jadi, orang tua tidak harus membayar langsung ke sekolah meskipun pelayanan pembayaran juga diperbolehkan lewat akses biasa.

\section{c. Strategi Place}

Lokasi Sekolah Alam Baturraden yang berada di kaki gunung Slamet di lokasi hutan Damar yang dikelola oleh Perhutani, memiliki jarak sekitar $16 \mathrm{~km}$ dari pusat kota Purwokerto. Memiliki udara yang sangat sejuk karena terdapat di daerah yang asri dan juga jauh dari polusi udara pada umumnya.

Di daerah lokasi tersebut memiliki sumber belajar yang luar biasa banyak seperti hutan, sungai, air terjun, lokawisata, bumi perkemahan, kebun raya, tebing, rumah produksi, perkebunan dll. Adanya sarana yang telah ada tersebut merupakan laboratorium alam yang luar biasa baik sebagai sumber belajar bagi peserta didik. Lokasi tersebut memang memiliki sedikit tantangan bagi para pengguna jasa pendidikan di SD Alam Baturraden tersebut karena lokasinya yang berada di hutan. Akan tetapi dari tantangan tersebut lahirlah kesempatan yang baik sebagai pembelajaran kemandirian bagi seluruh peserta didik agar terbiasa melalui medan yang sedikit terjal dan tidak seperti yang biasanya mereka temui.

Adanya keunikan tersebut mengundang berbagai praktisi pendidikan dari berbagai wilayah regional, nasional maupun internasional. Dan beberapa tahun mendatang di mana semakin 
panasnya udara di daerah perkotaan, maka sekolah tersebut pun akan memiliki perhitungan lebih berdasarkan posisi lokasi tersebut.

\section{d. Strategi Promotion}

Ada dua strategi promosi yang secra umum digunakan oleh pemasar jasa pendidikan yaitu strategi pemasaran below the line dan strategi pemasaran above the line. SD Alam Baturraden merupakan sekolah yang memasarkan jasa pendidikannya dengan konsep yang pertama, yakni below the line. Sistem pemasaran below the line memasarkan jasa pendidian melalui kegiatankegiatan yang mendeskripsikan serta menunjukan prestasi dan kemampuan yang dimiliki oleh sekolah tersebut seperti melalui kegiatan kemasyarakatan, pentas musik di berbagai kegiatan, seminar pendidikan, mengadakan kegiatan inklusi maupun mengisi seminar inklusi, mengikutsertakan peserta didik ke dalam berbagai perlombaan, mengadakan kegiatan outbound bagi masyarakat umum di lokasi sekolah.

Sistem yang diambil oleh SD Alam Baturraden dalam mempromosikan jasa pendidikan tidak serta merta dirasakan hasilnya seketika, tetapi melalui tahap yang pasti dan juga unjuk kualitas diri. Hal ini karena memang prinsip dari sekolah tersebut adalah sekolah "butik". Sekolah butik di sini bukanlah sekolah dengan pembiayaan selangit yang diperuntukkan bagi kalangan menengah keatas, melainkan sekolah yang diminati oleh orangorang yang memiliki kualitas pendidikan yang baik yang menyadari pentingnya pendidikan bagi anak.

\section{e. Strategi People}

Strategi sumber daya manusia ini memegang peran yang sangat penting bagi kelangsungan proses kegiatan dan juga pelayanan jasa pendidikan di SD Alam Baturraden. Hal ini sangat disadari sehingga muncullah berbagai sistem yang diterapkan bagi kemajuan sumber daya manusia itu sendiri.

Hal ini dapat dibuktikan dari berbagai aktivitas yang dilakukan di sekolah alam tersebut seperti pelatihan bagi pengajar maupun tenaga administrasi di antaranya seperti teaching clinic yang dilakukan secara berakala setiap pekan, up-grading, outbound 
fasilitator, mendatangkan guru tamu, mengikuti seminar, workshop, bergabung dalam Jaringan Sekolah Alam Nasional, beasiswa S1 dan lain sebagainya.

Dalam perekrutannya pun melalui beberapa tahap yang harus dilalui oleh calon pengajar seperti:

1. Rekrutmen, di SD Alam Baturaden, pengajar tidak diwajibkan hanya berasal dari kalangan pendidikan saja, akan tetapi juga dari lulusan beberapa disiplin ilmu non-kependidikan. Hal ini terkait dengan tujuan sekolah tersebut yang ingin menjadikan siswa memiliki berbagai wacana keilmuan yang luas yan bersumber dari para guru pengajar.

2. Staffing, penempatan jabatan ditentukan oleh pengelola sekolah.

3. Pelatihan kinerja, seperti yang telah dijabarkan di atas.

4. Evaluasi kinerja, dilakukan setiap 6 bulan sekali seperti diadakannya progress report bagi para pengajar dan juga administrasi.

5. Restaffing, yakni menganalisis penempatan kembali setelah evaluasi.

6. Pelepasan, hal ini ditujukan bagi yang mengundurkan diri maupun bagi yang di bebas tugaskan.

\section{d. Strategi Physical evidence}

Bukti fisik yang di tampilkan dari Sekolah Alam Baturraden tentunya berbeda dengan bukti fisik yang dimiliki oleh sekolah pada umumnya. Hal ini disebabkan karena sekolah alam merupakan sekolah yang ramah lingkungan sehingga dari segi bangunannya pun hanya 30 persen yang memiliki bangunan permanen sementara yang lainnya adalah bangunan semi permanen seprti saung sebagai kelas belajar. Selain saung yang merupakan tempat sekunder bagi proses pembelajaran, Sekolah Alam Baturraden memiliki open space yang cukup luas sekitar 3,5 hektar hutan yang dijadikan sebagai masjid, 3 saung, kantor, dapur, kamar mandi, lapangan, Michel Garden, Green House, labirin, bukit, rumah pohon, area outbound, taman, dan ruang terbuka sebagai tempat belajar. 


\section{e. Strategi Process}

Dari aspek kurikulum, Sekolah Alam Baturraden mengikuti standar yang telah ditetapkan oleh Kementrian Pendidikan Nasional. Hal ini dapat dilihat dari muatan mata pelajaran maupun kegiatan yang dilakukan oleh SD Alam Baturraden. Akan tetapi dalam hal penyajian SD Alama Baturraden memiliki ciri khas tersendiri dari sekolah alam. Kegiatan pembelajaran dilakukan secara terintegrasi dan juga belajar langsung dari alam dan berbasis pengalaman. Pembelajaran yang ditanamkan bukan berupa hafalan akan tetapi nilai-nilai dan pemahaman. Pembelajaran yang dilakukan oleh SD Seolah Alam tidak hanya sekedar distandarkan oleh Diknas saja akan tetapi lebih dari itu, sekolah alam Baturraden membawa pembelajaran siswa dengan lebih dalam dan menyentuh ranah islamika, baik secara praktek maupun penanaman nilai.

Setiap keluhan, usulan, aspirasi yang disampaikan oleh orang tua di tampung dengan baik dan dibicarakan secara formal dan bersifat kekeluargaan.

\section{Kesimpulan}

Dari pembahasan tersebut, dapat disimpulkan bahwa pendidikan merupakan investasi masa depan yang sangat urgen. Oleh karena itu sangat dibutuhkan adanya kualitas pendidikan dengan mutu yang baik pula. Melalui pemasaran pendidikan, peningkatan mutu dapat memberikan berbagai manfaat bagi lembaga pendidikan baik bagi konsumen pendidikan maupun income dan output lembaga pendidikan tersebut. Dalam pemasaran jasa pendidikan terdapat unsur-unsur yang sangat penting dan dapat dipadukan sedemikian rupa sehingga dapat menghasilkan strategi pemasaran yang dapat digunakan untuk memenangkan persaingan. Bauran pemasaran merupakan alat bagi pemasar yang terdiri atas berbagai unsur suatu program pemasaran yang perlu dipertimbangkan agar implementasi strategi pemasaran dan positioning yang ditetapkan dapat berjalan sukses. Bauran pemasaran terdiri dari $7 \mathrm{P}$ yaitu product, price, place, promotion, people, physical evidence dan process. 


\section{LL-Tarbawj Afidatun Khasanah}

\section{Daftar Pustaka}

Hidayat, Ara dan Imam Machali. Pengelolaan Pendidikan. Pertama. Bandung: Pustaka Educa, 2010.

Wijaya, David. Pemasaran Jasa Pendidikan. Jakarta: Salemba Empat, 2012.

Machali, Imam dan Ara Hidayat. The Handbook of Education Management. Yogyakarta: Magister Pendidikan Islam Universitas Islam Negeri Sunan Kalijaga, 2015.

Asmani, Jamal Ma'mur. Manajemen Efektif Marketing Sekolab Pertama. Yogyakarta: DIVA Press, 2015.

Kotler, Philip. Marketing Management International Edition, New Jersey: Prentice Hall Inc, 2003. 